\title{
Exercising Democratic Rights and Obligations as a Mechanism for Improved Service Delivery: The Case of Kampala City, Uganda
}

LUBINGA, S.N. | du PLESSIS, L.M.

\section{Abstract}

manating from literature (Ministry of Local Egovernment 2013:10; Gaventa 2002: p.26; Odero 2004: p.2), it is apparent that participatory frameworks exist in Uganda. However, in spite of a two decade-plus long prevalence these democratic participatory frameworks, the services rendered to the citizens are still poor. For instance, the delivery of health services has remained pitiable and the majority of people have turned to private hospitals. The provision for adequate infrastructure for the children enrolled in primary schools remains a challenge to the education sector. Yet, access to safe water is estimated at as low as $9 \%$ in some districts, while an estimated $19 \%$ of the improved water supply systems are still not functioning (UBOS, 2010: pp.33-57). This is not only attesting the statement that participatory initiatives in Uganda are more like "wish lists" than substantive statements that are guaranteed in practice, but also raising the research question as to what extent does the exercise of democratic rights and obligations of citizens by citizen's impact on public service delivery in Uganda?

In answering this question, this paper applied a quantitative research method in which a self-administered questionnaire survey based on three variables used to measure the exercise of democratic rights and obligations was distributed to a representative sample of 100 participants from Kampala city selected from three urban division councils (Kawempe, Makindye and Kampala Central). Thereafter, using the ordered logistic regression model of analysis, constructed on the findings the paper divulges that the exercise of democratic rights and obligations by citizens has a positive implication towards quality service delivery.

Keywords: Democratic Rights and Obligations; Citizen Participation; Public Service Delivery; Kampala; Uganda. 


\section{INTRODUCTION AND BACKGROUND}

In spite of the fundamental assumption that more effective accountability mechanisms will encourage improved service provision (Acosta, 2010: 5), comparative studies of the factors that account for deviation in service delivery outcomes are somewhat rare or are not reflecting the true nature of what is happening on the ground. For instance, irrespective of a two decade-plus long prevalence of several democratic participatory frameworks, and the excellent legal and policy frameworks for exercising of democratic rights and obligations of citizens in Uganda. Such as; the 1995 constitution of Uganda that provides for the Bill of Rights and stipulates that the exercise and enjoyment of rights and freedoms are inseparable from the performance of duties and obligations of citizens. The decentralization policy guided by the Local Government Act of 1997 as amended in 2001, the Decentralisation Policy Strategic Framework (DPSF), the Fiscal Decentralization Strategy (FDS), the Local Government Sector Strategic Plan (LGSSP), the Public Sector Management Strategic Investment Plan (PSM-SIP) and the National Development Plan (NDP) (Ministry of Local government 2013:10).

The district Budget conferences geared at bringing together stakeholders, including private sector, CSOs, development partners and the wider public - including grassroots people - organised by the district soon after the first Regional Local Government Budget Framework Paper (LGBFP) workshops in October (Gaventa 2002: p.26; Odero 2004: p.2). The Poverty Eradication Action Plan (PEAP) also known as the national planning framework that guides detailed medium-term sector plans, district plans, and the budget process (Kakumba 2010: p.183). Over and above the presence of institutions that protect democracy and promote human rights, i.e. the Public Accounts Committee (PAC), the Public Procurement and Disposal of Public Assets Authority (PPDA), and the Inspectorate of Government (IGG). Services especially those related to the PEAP sectors (education, Health, water and roads) rendered to the citizens are still poor.

For instance, the delivery of health services has remained pitiable and the majority of people have turned to private hospitals. This is attributed to staff shortages at public hospitals that are further compounded by absenteeism and the inability to retain critical specialists (The Parliament of Uganda 2012: 5).

Additionally, there is the problem of deteriorating access to drugs/medicines in health units, coupled with poor management at health unit levels, as well as underfunding of the health sector. This is reflected in the high number of maternal 
deaths ranking Uganda's maternal health as one of the worst in Africa and accounting for $2 \%$ of annual maternal deaths globally. This translating into 492 maternal deaths per month and roughly 16 deaths per day (UBOS, 2010: 116; Kabayambi 2014: 1). Moreover, although community roads are the nearest type of road to the majority of households, as per the national service delivery survey, these roads are characterized by poor maintenance (UBOS 2010: XVI).

In the case of education, despite the fact that adequate infrastructure is a key essential interventions in improving equitable access to education at all levels as highlighted in the National Development Plan education priorities. According to Uganda Bureau of Statistics UBOS (2010: p.9) provision for adequate infrastructure for the children enrolled in primary schools remains a challenge to the education sector with approximately one in every three pupils enrolled in primary schools not having adequate sitting and writing space (World Bank 2013:2).

Additionally, the service delivery situation in the water and sanitation sector is also alarming within the Ugandan populace - especially among children. Such that on average, access to safe water is estimated at as low as $9 \%$ in some districts, while an estimated $19 \%$ of the improved water supply systems are still not functioning (UBOS, 2010: pp.33-57).

Therefore, the fact that it is widely hypothesised that the existence of effective accountability mechanisms encourages improved service provision. (Blair 2000: 23; Narayan 2002: 14; Fox and Meyer 1995: 20). In light of the above discussions, it is clear that although the necessary initiatives on which the exercise of democratic rights and obligations of citizens can be anchored exist in Uganda, true nature of the status of service delivery in Uganda amidst the presence of these frameworks is somewhat tainted. Thus, it is against this background that this paper aims to establish whether the quality public service delivery relates to the exercising of democratic rights and obligations of citizens by citizens.

The structure of this paper is as follows. The following section presents a detailed discussion on the fundamental catchphrases that reinforce the imperatives of exercising democratic rights and obligation of citizens as well as the significance of exercising democratic rights and obligations of citizens as an essence of enabling good public service delivery across nations. Thereafter, using results from a quantitative questionnaire survey based on three variables notably: broad participation, citizen satisfaction and 
aftermaths of citizen participation the hypothesis is tested. Then lastly the findings, conclusion and recommendations for exercising democratic rights and obligations of citizens to improve public service delivery in Kampala are presented.

\section{FUNDAMENTAL CATCHPHRASES THAT REINFORCE THE IMPERATIVES OF EXERCISING DEMOCRATIC RIGHTS AND OBLIGATION OF CITIZENS}

Despite the fact that to-date it is almost impossible to talk about people, power and politics without also discussing the concepts democracy, human rights and citizen responsibilities. Familiarity with the notion exercising democratic rights and obligations for many is still highly misunderstood and often misused. For instance, since the 1970s, with the utmost emphasis on the free market economy, most liberals have traded the language of civic duties and obligations for the language of rights. The majority now fronting the need to recognise and respect individual human rights as opposed to the need to promote these civic rights together with civic obligations and responsibilities (Kloppenberg, 2012: 12). Hence, for the purpose of this paper, the following section seeks to unravel fundamental catchphrases that reinforce the imperatives of exercising democratic rights and obligation of citizens, which at the same time will underpin the ideals of good service delivery. These catchphrases are: democratic rights, democratic obligations and citizen participation.

\section{Democratic rights}

Raveloson (2008:4) asserts that rights are much more than mere components of a democracy, representing the sine qua non requirements of well-performing democratic systems. They are inherited to the individuality of each person in terms of protection against any inclination of the state to human beings; individuals are born with them and not even the state can withdraw them from individuals; and they form the very core of human relations that guide life in society at all levels within democratic systems.

Furthermore, Raveloson (2008:4) recognises that rights evolve in four different fields, namely:

- Individual personality rights - constituting of the core human rights such as the right to life and the right to free personality developments; 
- Political civil rights - entailing those rights that ensure each citizen is able to participate without any restrictions to the political life of his/her community, i.e. freedom of speech, freedom of the press, freedom of holding meetings, and also being able to set up associations;

- Socio-economic rights - emphasizing all rights in relation to the minimum standard wage for survival, i.e. right to education; and

- Last but not least, the generation rights - demonstrating that human rights can evolve and are not fixed at the starting point, i.e. right to development aimed at reducing the gap between the right and power, and the environmental rights.

Likewise, in the words of Thomas Jefferson (1776), rights cannot be legislated away nor should they be subject to the whim of an electoral majority. For any democratic government worthy to be called so, the government must at least uphold fundamental rights, such as freedom of speech and expression and the right to equal protection before the law amongst others (Bureau of International Information programs 2012: 12).

According Torney-Puta 1998 in: Sifuna (2002:17), rights are those entitlements which are basic to being human and are not connected to the accident of being born in a certain country or having a different skin colour. Rights include basic rights that deal with the dignity and worth of a person; civil and political rights; and social, economic and cultural rights that emphasise matters such as the right to work, the right to maintain one's culture and language, and the right to receive adequate education.

\section{Democratic obligations}

Although used synonymously with the words civic responsibility, according to Self (2012: 1), democratic obligations refer to the actions and attitudes associated with democratic governance and social participation, such as participation in government, society, and in voluntary activities by citizens. According to the Oxford Dictionary, an obligation is an act or course of action which a person is morally or legally bound to do that arises out of a sense of duty. Yet for Gottlieb and Robinson (2002: 16), obligations refer to the active participation in the public life of a community in an informed, committed, and constructive manner, with a focus on the common good. 
For the purpose of this paper, democratic obligations will be defined as the course of actions that an individual is morally bound to do that arise out of a sense of duty for any responsible citizen. These acts of actions, including focusing on the need to contribute to one's community and country; understanding that one's rights must exist in balance with other prerogatives; the commitment of oneself to the idea that political disputes should be resolved more or less amicably; and lastly to pledge loyalty to the ideals of reasoned debate, majority rule, and protections of minority rights (Eskridge, 2001:1725).

\section{Citizen participation}

Although often aligned or even interchangeably used to refer to democratic citizenship, citizen participation is commonly viewed as attempts to influence the formulation of public policy (Whitaker 1980: 240). For Gaventa and Valderrama (1999:4) citizen participation refers to political participation mediated by political parties, as well as the participation exercised by citizens when they elect political authorities.

\section{THE SIGNIFICANCE OF EXERCISING DEMOCRATIC RIGHTS AND OBLIGATIONS TOWARDS SERVICE DELIVERY}

In order to comprehend the significance of exercising democratic rights and obligations towards delivery, it is prudent to clarify what service delivery entails. According to the Ministry of Local government (2013: 1), service delivery refers to a relationship between policy makers, service providers, and consumers of those services, whose success can be a collaborative effort between all parties guided by effective and efficient exercise of democratic rights and obligations of citizens. As argued by Keefer and Khemani 2005: 6), the success or failure of service provision depends heavily on the private characteristics of the service recipients, such as how healthy, and academically astute they are. Exercising democratic rights and obligations of citizens derives government awareness, which helps government and policy makers to know exactly who needs what, where and when. It also helps policy makers learn which policies are likely to be explosive or unpopular and how to avoid such policy failures (Whitaker 1980: 240; Denhardt \& Denhardt 2000: 552 and Irvin \& Stansbury 2004: 56). 
Likewise, exercising democratic rights and obligations, especially in multiparty democracies, can vastly improve social outcomes, as balanced inputs from citizens participating allows political parties to compromise and find solutions to previously intractable problems (Irvin and Stansbury 2004: 57). In terms of the education and health sectors, according to Nelson (2007: 37), citizen participation may improve parents' and communities' understanding and knowledge of education and health services, encouraging them to contribute time, money and/or labour to support local facilities. Promotes accountability and better performance by health directors and staff and leads to more vigorous, and better-informed pressure on bureaucrats, legislators, and political leaders at all levels to improve service delivery performance (Gershberg, 2004: 429).

Additionally, exercising democratic rights and obligations strengthens beneficiary control (service providers' accountability to citizens), a critical element in service provision. This is especially true in democratic states that are rife with maladministration and corruption, where the institutions assigned to monitor service providers are weak and malfunctioning, and act under an incentive system that provides little incentives to effectively monitor the service providers (Bjorkman and Svensson 2007: 2). Moreover, given the fact that diversity in society is inevitable, citizen participation helps to bridge societal cleavages, creates civil virtues, and fosters social cohesion (Paffenholz and Spurk 2006: 8).

Conversely, exercising democratic rights and obligations encourages on-site participation by users of welfare services, based on the belief that citizens should personally engage in shaping the services they demand. It provides a bedrock for multistakeholder organisations to be formed and requires that users (the citizens) become coproducers of the services they require. This upholding of what is now known as "citizencentred service which helps highlight the challenge of access by positioning citizen satisfaction as the criterion for success and basis on which public sector service delivery can be measured" (Pestoff 2009: 203; Institute for Citizen-Centred Service (ICCS) 2013: Online).

\section{RESEARCH DESIGN AND METHODOLOGY}

Given that this paper sought to verify the existing set of defined variables, founded on the hypothesis that the exercise of democratic rights and obligations by citizens has a positive implication towards service delivery, this paper followed a quantitative research 
approach. Considering the entire population (1,720,000 people) of Kampala City (UBOS, 2002) as the study area and allowing for a 10\% level of significance, a sample size of 100 respondents was obtained as illustrated below.

$$
\begin{aligned}
& \quad n=\frac{17200000}{1+1720000(0.1)^{2}}=100 \text { respondents } \\
& \text { Sample size: } \\
& \mathrm{n}=100 \text { respondents }
\end{aligned}
$$

Israel (2013: 4).

Representatives were selected from three division urban councils to represent the citizens. For instance, from the entire sample $(n=100)$, the total number of respondents per division obtained was divided by the total population $(653,430$ people) of the three divisions (Kawempe, Makindye and Kampala Central), and multiplied by 100 giving the number of respondents per division as expressed below.

- Kawempe Division $=(262,165 / 653,430) * 100=40.1=40$ respondents;

- Makindye Division $=(303,171 / 653,430) * 100=46.4=46$ respondents; and

- Kampala Central Division $=(88,094 / 653,430) * 100=13.5=14$ respondents.

Upon ascertaining the required number of respondents at each division, simple random sampling techniques were used to select the participating households. The rationale behind this choice was to obtain the richest possible source of information to answer the research questions. Additionally, for the researcher to be able to acquire enough information that meets multiple interests and needs whilst fitting the purpose of the study.

Following the random sampling technique, irrespective of the lower level zone within the divisions, comprehensive lists of all households within each division were accessed at each Division's Head Offices through the Electoral Commission registers, after which a random selection of household representatives was made. In particular, numbers were written on pieces of paper, rolled and then placed in a closed, dark basket. The pieces of paper were then randomly picked from the basket and checked. A corresponding number was then checked from the voter's register and the name of individual recorded. Household details of such a selected individual were taken and the selected individual located to take part in the study. In an event that no representative of the selected 
household was present at the time of completing the questionnaire, a respondent from the nearest household participated in the study.

\section{Measure of the Research Variables in the Study}

The empirical data needed was specifically directed at assessing the extent to which the exercising of democratic rights and obligations of citizens' impact on public service delivery in Uganda. To gather concrete evidence, as well as develop a standard measure for the exercise of democratic rights and obligations of citizens, in this study the measurable elements in the form of independent variables were identified, each of which were measured using indicators. The indicators are, namely:

- Broad participation:

1) Knowledge on democracy, responsibilities and citizen participation procedure;

2) Involvement in decision making process; and

3) Perceptions towards citizen participation initiatives.

- Citizen Satisfaction:

1) Satisfaction with the service delivery outcomes of the citizen participation process;

2) Satisfaction with the citizen participation process; and

3) Satisfaction with the performance of citizen participation facilitators.

- Aftermaths of citizen participation:

1) Consideration of citizen recommendations in decision-making (action);

2) Feedback; and

3) Communication.

\section{Statistical analysis and findings}

In this paper, data was analysed at a multivariate level, using an ordered logistic regression model to determine the factors within the variables responsible for quality of services delivered. Where only $p$-values of less than 0.05 were considered statistically significant. Similarly, to affirm whether the indicators within the identified variables (broad participation, citizen satisfaction and aftermath of citizen participation) were risk factors for the quality of service delivery. Odds ratios (OR) were used to compare the 
relative odds of the occurrence of the outcome of interest (public service delivery), given exposure to the variable of interest (broad participation, citizen satisfaction and aftermath of citizen participation). See Table 1 - Results of the Ordered Logit Regression Model Showing the Indicators Within the Variables That Affect the Quality of Services Delivered in Kampala City.

Table 1: Results of the Ordered Logit Regression Model Showing the Indicators With In The Variables That Affect The Quality Of Services Delivered In Kampala City

\begin{tabular}{|c|c|c|c|c|}
\hline Independent Variables & $\begin{array}{l}\text { Expected } \\
\text { sign of the } \\
\text { coefficient }\end{array}$ & Coefficient & p-value & Odd ratio \\
\hline \multicolumn{5}{|l|}{ BROAD PARTICIPATION } \\
\hline \multicolumn{5}{|l|}{$\begin{array}{l}\text { Knowledge of Democratic } \\
\text { characteristics }\end{array}$} \\
\hline Freedom of expression & + & -1.366617 & 0.012 & $.2549682 * *$ \\
\hline Freedom of press/media & + & -1.239543 & 0.004 & $.2895166^{* *}$ \\
\hline Equality before the law & + & -1.65738 & 0.000 & $.1906379 * *$ \\
\hline Free and fair election & + & -1.285585 & 0.002 & $.2764889 * *$ \\
\hline Religious freedom & + & -.6947 & 0.251 & $.4992242 * *$ \\
\hline Freedom of association & + & -1.175975 & 0.006 & $.3085179 * *$ \\
\hline Absence of discrimination & + & -1.332638 & 0.001 & $.2637805^{* *}$ \\
\hline \multicolumn{5}{|l|}{$\begin{array}{l}\text { Citizen involvement in decision } \\
\text { making process }\end{array}$} \\
\hline $\begin{array}{l}\text { Citizens involvement in the } \\
\text { planning process }\end{array}$ & + & -.8146723 & 0.024 & $.4427844 * *$ \\
\hline $\begin{array}{l}\text { Citizens involved in decisions } \\
\text { made }\end{array}$ & + & -3.535868 & 0.049 & $.0291334 * *$ \\
\hline \multicolumn{5}{|l|}{$\begin{array}{l}\text { Considering voices of different } \\
\text { community groups in decision- } \\
\text { making }\end{array}$} \\
\hline LC1 chairpersons & + & -.7107568 & 0.683 & $.4912723^{* *}$ \\
\hline Local councillors & + & 2.203726 & 0.035 & $9.058707^{* * *}$ \\
\hline Members of parliament) & + & 2.258743 & 0.013 & $9.571047^{* * *}$ \\
\hline Lord mayor & + & 3.098618 & 0.001 & $22.1673 * * *$ \\
\hline KCCA & + & .8673317 & 0.319 & $2.38055^{* * *}$ \\
\hline Citizens & + & 3.010589 & 0.000 & $20.29935 * * *$ \\
\hline Civil servants & + & 2.101874 & 0.015 & $8.181486 * * *$ \\
\hline NGOs & + & 2.276525 & 0.000 & $9.742762 * * *$ \\
\hline
\end{tabular}


104 Africa's Public Service Delivery \& Performance Review

\begin{tabular}{|c|c|c|c|c|}
\hline Media & + & -1.237414 & 0.468 & $.2901336 * *$ \\
\hline \multicolumn{5}{|l|}{ CITIZEN SATISFACTION } \\
\hline Satisfaction with the services & + & -6.605573 & 0.000 & $.0013528 * *$ \\
\hline $\begin{array}{l}\text { Satisfaction with services } \\
\text { providers }\end{array}$ & + & -2.906735 & 0.007 & $.0546539 * *$ \\
\hline \multicolumn{5}{|l|}{$\begin{array}{l}\text { Satisfaction with the } \\
\text { Performance of leaders }\end{array}$} \\
\hline LC111 chairpersons & + & -1.239437 & 0.013 & $.2895471 * *$ \\
\hline Members of parliament & + & -1.338172 & 0.033 & $1.069816^{* * *}$ \\
\hline Lord Mayor & + & .3543571 & 0.506 & $1.425264 * * *$ \\
\hline \multicolumn{5}{|l|}{$\begin{array}{l}\text { AFTERMATH OF CITIZEN } \\
\text { PARTICIPATION }\end{array}$} \\
\hline $\begin{array}{l}\text { Local authorities report back } \\
\text { the people after service } \\
\text { delivery }\end{array}$ & + & 0.366617 & 0.015 & $1.2549682 * * *$ \\
\hline $\begin{array}{l}\text { Citizens are given feedback on } \\
\text { decision processes }\end{array}$ & + & -0.239543 & 0.043 & $0.1876166 * *$ \\
\hline $\begin{array}{l}\text { Citizens decisions are respected } \\
\text { by authorities }\end{array}$ & + & 1.95738 & 0.000 & $2.1306379 * * *$ \\
\hline $\begin{array}{l}\text { Community suggested solutions } \\
\text { are given adequate } \\
\text { consideration }\end{array}$ & + & -1.825585 & 0.002 & $.3964889 * *$ \\
\hline
\end{tabular}

The odds ratios interpreted as follows: * OR=1 Exposure does not affect odds of outcome; ** OR>1 Exposure associated with higher odds of outcome and $* * * \mathrm{OR}<1$ Exposure associated with lower odds of outcome.

Source: Self compiled. 


\section{VARIABLE 1: BROAD PARTICIPATION AS DETERMINANT OF QUALITY SERVICE DELIVERY}

Broad participation in this study was measured using sub-indicators, namely: knowledge of democratic characteristics, citizen's responsibilities, citizen participation procedures, access to citizen participation initiatives, citizen involvement in decision-making processes, and perception towards citizen participation initiatives. All of which were explored in the survey as presented in the findings below.

\section{Democratic characteristics as determinants of quality of service delivery}

From Table 1, regression results reveal that six out of the seven democratic characteristics have a statistically significant relationship with the quality of services delivered. All seven have negative coefficients, irrespective of expected positive coefficients based on literature. For example, freedom of expression as a determinant of public service delivery was seen to be significant at $(p=0.012)$ with a negative coefficient $(\beta=-1.367)$. This means that the reduction in freedom of expression by one unit will result in the reduction of the quality of public services delivered in Kampala communities from very good to very poor by 0.255 odds. Therefore, the fact that freedom of expression empowers communities to take a leading role in decisions that affect their lives within their communities, gaining the ability to influence quality of all services delivered, is very important.

Also based on Table1, regression results indicated a negative coefficient $(\beta=-1.240)$ for freedom of press/media as a determinant of quality public service delivery from the analysis despite the significance of the result $(p=0.004)$. The negativity denoting that a reduction in freedom of press/media by one unit results in the reduction of the quality of public services delivered in Kampala from very good to very poor by 0.290 Odds. The researcher deduces that communities that have press/media freedom are more likely to have quality services delivered in their areas compared to those that do not have any press/media freedom. Therefore, as a democratic indicator, practising freedom of press/media within the governance structure of any country or district, greatly contributes to improving quality of service delivery due to its ability to popularise within the communication systems for people to have information adequate enough to be able to influence change within their communities. 
For equality before the law as a determinant of quality of public service delivery, regression results showed a statistically significant relationship $(p=0.000)$ and a negative coefficient $(\beta=-1.657)$. This implies that equality before the law is an important characteristic of democracy and that has a critical effect on service delivery whereby a reduction in equality before the law of all people irrespective of their differences by one unit surely results in the reduction of the quality of public services delivered in Kampala from very good to very poor by 0.191 odds. This rightly in principle implies that acknowledging equality within communities can have a considerable change in the quality of services delivered within society, which consequently can result into a change in way of life within communities.

Additionally, hypothetically having free and fair elections in any society contributes to a sense of direction that promotes democracy in that society, resulting into stability and consequently improved services to the people. Also, the regression analysis for the subindicator free and fair election was statistically significant $(p=0.002)$ though the coefficient was negative $(\beta=-1.286)$. This implies that a reduction in opportunity for free and fair elections in communities of Kampala districts results into a reduction in the of the quality of public services delivered from very good to very poor by 0.276 odds. It is thus important to note that in societies where there are no systems to ensure free and fair elections, service delivery and quality of services will be poor.

Furthermore, although religion is an aspect that is controversial in many ways, such as its influence on development, both positively and negatively, for religious freedom as a determinant of quality of public service delivery, results depicted that there was no statistically significant relationship and the coefficient was negative $(p=0.251 ; \beta=-.6947)$. The negative coefficient, however, symbolising that infringement on citizens' religious freedom by even one unit leads to a reduction in the quality of services delivered from very good to very poor by 0.499 odds.

Freedom of association as a determinant of quality of service delivery was proved statistically significant from the regression results $(p=0.006)$ with a negative coefficient $(\beta=-1.176)$. The negative coefficient $(\beta=-1.176)$ signifies that a reduction in citizens' freedom of association results in the reduction of the quality of public services delivered in Kampala communities from very good to very poor by 0.309 Odds. Thus, as characteristic of democracy, referring to the right of an individual to belong to a certain group or organisation in which they have a common understanding and belief, practising 
freedom of association within the governance structure of any country or district out rightly contributes to improving quality of public service delivery.

Results for absence of discrimination as a determinant of quality of public service delivery indicated a statistically significant relationship with a negative coefficient $(p=0.001 ; \beta=-1.333)$. A negative coefficient of $(\beta=-1.333)$ denoting that a deterioration in non-discrimination practices results in the reduction of the quality of public services delivered in Kampala communities from very good to very poor by 0.264 odds. The practices of non-discriminatory policies in Uganda thus need to be enforced to ensure improvement in service delivery and free access to services for all.

\section{Citizen involvement in decision-making processes as determinants of quality of service delivery}

Regarding measuring citizens' involvement in planning processes as a determinant of quality of public service delivery, the regression results indicated a significant relationship and a negative coefficient $(\beta=-0.815, p=0.024)$. The negative in the coefficient indicating that a reduction in citizens' involvement in planning processes by one unit results in the reduction of the quality of public services delivered in Kampala communities from very good to very poor by 0.443 odds. It is thus critical to consider citizen involvement in the planning process to allow for ownership and improved service delivery within society, given the significance of the result $(p=0.024)$.

For citizens' involvement in decision-making as a determinant of quality of public service delivery, results showed a significant relationship and a negative coefficient ( $\beta=$ 3.536, $p=0.049)$. The negative in the coefficient $(\beta=-3.536)$ indicating that a reduction in citizens' involvement in decision-making processes by one unit results in the reduction of the quality of public services delivered in Kampala communities from very good to very poor by 0.029 odds. Therefore, for the successful exercise of democratic rights that can demand quality services to prevail, involvement of communities on decision-making is important according to the results.

Likewise, when it came to the sub-indicator 'considering voices of different community groups in decision-making' as determinant of quality of services, from Table 1 , results showed that out of the nine voices of different community groups in decisionmaking, seven had a statistically significant relationship with the quality of services. For instance, with regard to considering the voices of local councillors in decision-making as 
determinant of quality of services, regression result showed a statistically significant relationship between the two variables and a positive coefficient $(\beta=2.204, p=0.035$ ). This means that that for an increase in the level of influence on decision-making by local councillors by just one unit, a significant $(p=0.035)$ increase in quality of services is attained by 9.058 odds. Thus leading to the deduction that local councillors are very important in influencing decision-making on service delivery-related issues, and, therefore, need to be encouraged to get involved in service delivery decision-making processes.

Furthermore, considering the voices of Members of Parliament (MPs) in decisionmaking as a determinant of quality services, regression results showed a statistically significant relationship with a positive coefficient on the quality of services delivered $(\beta=$ 2.258, $p$ <0.013). The positive coefficient signifies that an increase in the level of consideration, the voice of parliamentarians by one unit increases the quality of services from very poor to very good by 9.571 odds. Therefore, based on the fact that considering the voices of MPs in decision-making as a determinant of quality services is very significant ( $p$-value 0.013 ), for effective delivery of quality services, results suggest that it is prudent to involve MPs at all levels of the planning process.

Additionally, considering the Lord Mayor's input in decision-making as determinant of quality of services also had a statistically significant relationship with quality of services and a positive coefficient at $(\beta=3.098 ; p=0.001)$. This is suggesting that an increased consideration of the in the Lord Mayor's input in decision-making by one unit increases the quality of services delivery by 22.167 odds. Therefore, for effective delivery of quality services, results suggest that it is prudent to take into consideration the voice of the Lord Mayor in decision-making.

Also, looking at considering the voices of civil servants in decision-making as determinant of quality of services, based on the regression results, there was a statistically significant relationship between the two variables and a positive coefficient observed ( $\beta=2.101, p<0.015$ ). These findings specifically revealing that an increase in the consideration of the voices of civil servants by one unit would result in an increase in the quality of services delivered by 8.181 odds from very poor to very good. This means that the quality of services delivered to local citizens when civil servants' voices are taken into consideration is twice as much as the quality of services that would be delivered without involvement of civil servants. Therefore, based on the results, it is imperative to 
encourage the consideration of civil servants in decision-making for the delivery of quality services.

Furthermore, with regard to considering the voices of None Governmental Organisations or Civil Society Organisations (NGOs/CSOs) in decision-making as determinant of quality of services, the regression results showed a statistically significant relationship and a positive coefficient $(\beta=2.276 ; p=0.000)$. This means that an increase in the level of consideration of the voices of NGOs/CSOs in decision-making by one unit would significantly $(p=0.000$ ) result in an improvement in quality of services from very poor to very good by 9.743 odds.

Last but not least, looking at the consideration of the media's voice in decisionmaking as determinant of quality of services delivered, from Table 1, results showed that there was no significant relationship whatsoever and the coefficient was negative too ( $p$ $=0.468 ; \beta=-1.237)$. This meaning that a reduction $(\beta=-1.237)$ in the consideration of the voice of the media in decision-making by one unit reduces the quality of services delivered. Thus implying that there is no significant relationship between the media and the services delivered is something that can lead to deduction that maybe it is because media just airs out or publishes what decisions have been made, but they have little to no power to influence decisions made.

\section{VARIABLE 2: CITIZEN SATISFACTION AS DETERMINANT OF QUALITY OF SERVICE DELIVERY}

From the satisfaction perspective as a variable for exercising democratic rights, three satisfaction indicators were used. Firstly, whether or not respondents were satisfied with services, secondly, whether respondents were satisfied with the service providers or not, and, thirdly, whether or not citizens were satisfied with the performance of citizen participation facilitators as revealed in Table 1 above.

For example, with regard to satisfaction with the services as a determinant of quality services, results showed that there was a statistically significant relationship and a negative coefficient $(\beta=-6.606 ; p=0.000)$. This indicates that a reduction in the level of satisfaction with the services by one unit would significantly $(p=0.000)$ result in decreased quality of services offered by 0.01 odds. Additionally, with satisfaction with service providers as a determinant of quality of services, based on Table 1, results showed a significant relationship and a negative coefficient $(p=0.007 ; \beta=-2.907)$. This 
means that a decrease $(\beta=-2.907)$ in the level of satisfaction with services providers would significantly ( $p=0.007$ ) lead to reduction of quality of services by 0.546 odds.

For satisfaction with the performance of citizen participation facilitators as a determinant of quality of services, results pertaining to the satisfaction with the level of performance by LC111 as a determinant of quality service delivery showed a statistically significant relationship and a negative coefficient $(p=0.013 ; \beta=-1.239)$. This means that a reduction ( $\beta=-1.239$ ) in the level of performance by LC111 by just one unit would significantly $(p=0.013$ ) lead to a reduction in quality of services delivered by 0.289 odds.

Likewise, satisfaction with the performance of Members of Parliament as a determinant of quality of services delivered, results showed a statistically significant relationship and a negative coefficient ( $p=0.033 ; \beta=-1.338$ ). This also implies that a reduction in performance of MPs would significantly $(p=0.033$ ) lead to a reduction in quality of services delivered by 1.069 odds. Satisfaction with the performance of the Lord Mayor as a determinant of quality of services delivered, results showed a positive coefficient and no significant relationship. This means that although an increase in the satisfaction of the performance of the Lord Mayor increases the quality of services, there is no significant relationship between the two variables.

\section{VARIABLE 3: AFTERMATH OF CITIZEN PARTICIPATION AS A DETERMINANT OF QUALITY OF SERVICE DELIVERY}

Just like broad participation and citizen satisfaction, to establish the determinants within the independent variable (aftermath of citizen participation) responsible for quality of services delivered, aftermath of citizen participation was measured specifically looking at action taken on recommendations, feedback and communication to citizens of the next step after participation. All represented in the following statements: Local authorities often report back to the people after service delivery; citizens are given feedback on decision-making processes; citizens' decisions are always respected by the authorities; and solutions proposed by the community are given adequate consideration, as depicted in Table 1, discussed below.

For the sub-indicator local authorities often report back to the people after service delivery as a determinant of quality of services delivered, just like the expected 
coefficient sign based on literature, regression results indicated a positive coefficient and a statistically significant relationship ( $p=0.015 ; \beta=0.366$ ). This means that an increase in reporting back to citizens by one unit results in the increment of the quality of public services delivered in Kampala communities from very poor to very good by 1.254 odds. It is thus very important to consider reporting back to citizens since it significantly ( $p=$ 0.015 ) influences the quality of services delivered at a $5 \%$ level of significance.

Likewise, with regard to giving feedback to citizens on decision processes as a determinant of quality of services delivered, results showed a negative coefficient and a statistically significant relationship $(\beta=-0.239 ; p=0.043$ ). This implies that a reduction in giving feedback to citizens significantly reduces $(\beta=-0.239 ; p=0.043)$ the quality of services by 0.239 units.

Respecting citizens' decisions as a determinant of quality of services delivered on the other hand, the results of the ordered Logit showed a statistically significant relationship $(p=0.000)$ and a positive coefficient $(\beta=1.95738)$. This means that respecting or honouring citizens' decisions enhances delivery of quality of services by almost twice (1.957) units as compared to the quality of services rendered in communities in which citizen's opinions are not taken into consideration.

For the indicator 'community suggested solutions are given adequate consideration', a determinant of quality of services delivered, based on Table 1, there was a statistically significant relationship and a negative coefficient. Thus implying that from the results, a reduction in taking into consideration community-suggested solutions significantly leads to a reduction in the quality of services $(\beta=-1.825, p=0.002)$. Therefore, giving adequate considerations to community-suggested solutions is also a very important factor to consider if a service provider is to provide quality services.

\section{FINDINGS AND IMPLICATIONS}

Based on the descriptive statistical analysis results, the research has the following findings and implications. First and foremost, most of the sub-indicators had a statistically positive relationship with service delivery in Kampala, the sample area. For example, under the broad participation indicator, regression results reveal that six out of the seven democratic characteristics have a statistically significant relationship with the quality of services delivered. Regarding citizens' involvement, results showed a statistically significant relationship towards involving citizens both in planning processes 
and decision-making processes as a determinant of quality of public service delivery. Moreover, considering voices of different community groups in decision-making as determinant of quality of services, results showed that out of the nine voices of different community groups in decision-making, seven had a statistically significant relationship with the services delivered.

Secondly, from the citizen satisfaction perspective, as an indicator for exercising democratic rights, satisfaction with the services as a determinant of quality services, and satisfaction with service providers as a determinant of quality of services, results showed that there was a statistically significant relationship. Moreover, satisfaction with the performance of citizen participation facilitators as a determinant of quality of services out of the three categories of participants considered, results showed that two (LC11 Chairpersons and Members of Parliament) had a significant relationship.

Thirdly, regarding the aftermath of citizen participation, for all the sub-indicators used, namely local authorities often report back to the people after service delivery, citizens are given feedback on decision-making processes; citizens' decisions are always respected by the authorities, and solutions proposed by the community are given adequate consideration, thus results showed a significant relationship towards the quality of services delivered in Kampala.

From the findings above, it can be suggested that the exercise of democratic rights and obligations of citizens by citizens has a positive implication towards quality service delivery.

\section{CONCIUSION AND RECOMMENDATIONS}

Drawing from the empirical findings above, and existing literature, conclusions are reached that despite the existence of initiatives on which the exercise of democratic rights and obligations of citizens can be anchored exist in Uganda. The true nature of the status of service delivery in Uganda amidst the presence of these frameworks is somewhat tainted. More over empirical data proves that the exercise of democratic rights and obligations of citizens by citizens has a positive implication towards quality service delivery. Therefore, the fact that fact that undesirable effects upon service delivery in Uganda still exist despite the presence of participatory frameworks, this paper is of the view that the following recommendations can be adopted. 
First and foremost, with regards to broad participation indicator, exercising democratic rights and obligation of citizens within the district should be a process that all district personnel at the five local council levels are aware of. This is mainly to ensure a standardised know-how on the importance of citizen participation in turn allows for an improved receptivity of citizen input. Therefore, based on the statistically significant relationship towards involving citizens both in planning processes and decision-making processes as a determinant of quality of public service delivery, it can be recommended that government in partnership with Non-government Organisations and Community Based Organisations provide continuous, wide-ranging education to the citizens. That is: education on the comprehensive planning process as a mechanism of awareness of the underlying policy issues of city planning and importance of participate. Education on advocacy, alliance formation and collaboration to encourage citizens be the advocates of change, as well as be able to form collaborate partnerships - especially those that cut across power differences and guard against co-optation. Lastly education on affective competencies and choice of values emphasising the fact that citizenship cannot be reduced to a catalogue of rights and duties; it also entails belonging to a group or to groups - thus requiring a personal and collective affective dimension.

Secondly, based on the performance of citizen participation facilitators as a determinant of quality of services, it can be recommended that government reemphasises the training and sensitising of the citizen participation facilitators - especially in areas of participatory planning, advocacy, alliance and collaboration. This mainly to capacitate them to be able to recruit new stakeholders in policy formulation as well as be able to review possible strategies for popular participation.

Thirdly, given the significance of the aftermath of citizen participation towards service delivery, it can be recommended that KCCA together with other districts adopt a clear comprehensive institutional community participation structure. A structure indicating who reports to whom, who is in charge of what, how is one supposed to participate, and what happens after one participates. This precisely to improve the lines of communication and encourage feedback on citizen participation. As well as provide an organised and accessible process by which the city receives and responds to input from every division on planning and development decisions in a timely fashion. 


\section{List of References}

- Barber, B. R. 1984. Strong Democracy: Participatory Politics for a New Age. University of California press.

- Blair, H. 2000. Participation and Accountability at the Periphery: Democratic Local Governance in Six Countries. Journal of World Development, Vol. 28: pp21- 41.

- Bjorkman, M and Svensson, J. 2007. Power to the people: Evidence from a randomized field experiment on Community-Based monitoring in Uganda. Online: http://www.povertyactionlab.org/publication/power-people-evidence-randomized-fieldexperiment-community-based-monitoring-project-uga Accessed on 2nd February 2012

- Bureau of International Information programs 2012, Democracy in Brief. Online: http://photos.state.gov/libraries/amgov/30145/publications-english/democracy-in-brief.pdf. Accessed $2^{\text {nd }}$ February 2012.

- Cornwall, A. 2013. Cultures of Politics, Spaces of Power: Contextualizing Brazilian Experiences of Participation. Journal of Power, Vo.6 (2). pp. 309-333. ISSN 1754-0291.

- Denhardt, R.B. \& Denhardt, J.V. 2000. The New Public Service: Servicing Rather than steering. Public Administration Review; November/December 2000, vol.60 (6)

- $\quad$ Eskridge. W. N. Jr. 2001. Relationship between Obligations and Rights of Citizens. Fordham Law Review Journal 2001, vol, 65 (5), pp1721-1751.

- $\quad$ Fox, W \& Meyer, I. H. 1995. Policies for Public Service Transformation. Eliot Avenue: Creda Press.

- Gebrezghi, B. 2013. Towards a better understanding of civil society: Building support for civil society-led assessments foundation for future. UNDP- Jordan publication.

- Gaventa, J and Valderrama, C. 1999. Participation, Citizenship and Local Governance. Institute of Development Studies, June 21-24. Online: http://www.uv.es/ fernandm/Gaventa,\%20Valderrama.pdf Accessed 20 May 2013.

- Gershberg, A. 2004. Empowering parents while making them pay: Autonomous schools and education reform processes in Nicaragua. In R. Kaufman and J. Nelson (Eds.) Crucial needs, weak incentives: Social sector reform, democratization and globalization in Latin America (pp. 407-437). Woodrow Wilson Centre Press and John Hopkins University. 
- Gottlieb, K and Robinson, G 2002. A Practical Guide for Integrating Civic Responsibility into the Curriculum. Online:

http://www.aacc.nche.edu/Resources/aaccprograms/horizons/Documents/cr_guide_2nd.pdf Accessed on 12 May 2015.

- Hileman, T. 2006. Democracy and Our Civic Responsibilities. Online: http://www.nysec.org/uploads/nysectalk061015.pdf Accessed on 1st September 2012.

- Irvin, RA and Stansbury, J. 2004. Citizen Participation in Decision making: Is it worth the effort? Public Administration Review, Vol, 64(2004): pp. 55-65.

- Israel, G. D. 2013. Determining the Sample Size. Online: http://edis.ifas.ufl.edu/pdffiles/PD/PD00600.pdf . Accessed on 20th May 2013.

- Institute for Citizen-Centred Service (ICCS) 2013. Citizen Centred service. Online: http://www.iccs-isac.org/about/citizen-centred-service/?lang=en. Accessed on 12 May 2013.

- Kakumba, U. 2010. Local government citizen participation and rural development: reflections on Uganda's decentralisation system. International Review of Administrative Sciences 2010 pp76-171 http://ras.sagepub.com/content/76/1/171 Accessed on 20 May 2012.

- Kabayambi, J 2014. Global trends in Maternal Mortality: How does Uganda Fare? Online: http://www.cehurd.org/2014/06/global-trends-in-maternal-mortality-how-does-ugandafare/ Accessed on 12 $2^{\text {th }}$ May 2015.

- Keefer, P and Khemani, S. 2005. Democracy, Public Expenditure and the poor: Understanding incentives for providing public services. Online; http://wbro.oxfordjournals.org/content/20/1/1.full.pdf. Accessed on 12 April 2013.

- Kloppenberg, J.T. 2012. Restoring the Language of obligation. Online: http://www.democracyjournal.org/24/restoring-the-language-of-obligation.php?page=all . Accessed: 20 May 2012.

- Nelson, J.M. 2007. Democratic Politics and Pro-poor Social Services: Unpacking the Concept of "Reform", in the politics of Service delivery in Democracies Better Access for the Poor Eds, Danvarajan, $\mathrm{S}$ and Windlund. Online: http://www.sarpn.org/documents/d0002962/Politics_SD_EGDI_2007.pdf Accessed on 3rd May 2012.

- Narayan, L. 2002. Empowerment and Poverty Reduction: A sourcebook. World Bank: Washington DC. 
- Paffenholz, T and Spurk, C. 2006. "Civil Society, Civic Engagement and Peace building." Research paper commissioned by the Social Development Department of the World Bank. Washington, DC: World Bank. Paris.

- Pestoff V. (2009) "Towards a paradigm of democratic participation: citizen participation and co-production of personal social services in Sweden", Annals of Public and Cooperative Economics, 80, pp. 197-224.

- Odero, K. K. 2004. PRSPs in Decentralized Contexts: Comparative Lessons on Local Planning and Fiscal Dimensions. Online: http://www1.worldbank.org/publicsector/decentralization/June21seminar/Uganda\%20Repor t.pdf Accessed on 20th May 2012.

- Parliament of Uganda. 2012. Infrastructure Developments in Roads, Railways and Energy. Online: http://www.statehouse.go.ug/national-priorities/infrastructure-development-roadsrailways-and-energy Accessed 20 September 2014.

- Raveloson, J. A. 2008. What is Democracy? Online: http://library.fes.de/pdffiles/bueros/madagaskar/05860.pdf. Accessed on 18 May 2013.

- Self, J. 2012. Civic Responsibility. Online: http://learningtogive.org/papers/paper11.html Accessed on 20 May 2012.

- Sifuna, D. (2000) Education for Human Rights in African Schools. African Development. Vol XXXV, Nos $1 \& 2$.

- Think Africa Press, 2013. Danger in Labour: Uganda's Maternal Health Crisis. Online: http://thinkafricapress.com/uganda/inside-southwestern-maternal-health-crisis-kabale. Accessed 20 September 2014

- Uganda Bureau of Statistics (UBOS). 2010. Statistical Abstract. http://www.countrystat.org/country/UGA/documents/docs/STATISTICAL\%20ABSTRACT\%202 010\%20-\%20UGANDA.pdf Accessed on 30 April 2011.

- Whitaker, G. P. 1980. Coproduction: Citizen Participation and service Delivery. Online: http://www.politicalscience.uncc.edu/godwink/PPOL8687/WK1\%20Jan\%2011\%20Market\%20 Failures/Whitaker\%20coproduction.pdf Accessed: 3rd August 2013.

- World Bank 2013. Education and Health Services in Uganda: Data for results and accountability. Online: http://wwwwds.worldbank.org/external/default/WDSContentServer/WDSP/IB/2013/11/18/000456286_2 0131118105216/Rendered/PDF/826660ESWOUgan090Box379862B00OUO090.pdf. Accessed: 9 February 2016. 
AUTHORS' CONTACT:

LUBINGA, S.N. du PLESSIS, L.M.

Independent Institute of Education Dept. of Public Admin \& Johannesburg, South Africa Management

Email: slunbinga@iie.ac.za University of Free State

Email: dplessIm@ufs.ac.za 